\title{
LAURENTIAN AND AFRICAN GREAT LAKES- DIFFERENT STRATEGIES IN THE FIGHT AGAINST INVASIVE SPECIES
}

\author{
Scott McKenzie \\ INTRODUCTION
}

Invasive exotic species are a reality in all ecosystems. These biological invaders disrupt ecological patterns and cause billions of dollars in economic damage. Justifiably, governments are stepping up their response. However, while many invaders are considered unmitigated ecological disasters, a number of species have become important and controversial parts of the regional economy.

In the Laurentian Great Lakes, the invasive species issue has been addressed through a number of unilateral and multilateral attempts at the state, national, and international level. This "law of the lakes" has evolved towards the implementation of the Great Lakes Water Quality Agreement of 2012, which uses a framework-protocol basis to combat the problem through a preservation-focused ecosystem approach. The management of water and fisheries in the African Great Lakes has similar problems addressing invasive species. ${ }^{1}$ However, states in this region have responded to the threat differently, particularly as it pertains to economically viable invasive fish species. Various state-level legislation and policy shows that the invasive threat is acknowledged, but follows a conservation management approach, which hopes to maintain the essential economic opportunities that the invasive species provide for area residents. The experiences of the Laurentian Great Lakes in moving their invasive species management forward can be used as a template to update and focus the response in the African Great Lakes.

\section{INVASIVE SPECIES THREATEN LAKE ECOSYSTEMS}

Invasive exotic species" are "successfully reproducing organisms transported by humans into regions where they did not exist in historical times." ${ }^{3}$ These invasive exotic species are one of the most widespread and

* J.D. University of Iowa. The author would like to thank Professor Haugeberg for her insight during early drafts of this Article.

1. See E. O. Odada \& D. O. Olago, Challenges of an Ecosystem Approach to Water Monitoring and Management of the African Great Lakes, 9 AQUATIC ECOSYSTEM HEALTH \& MGMT. 433 (2006).

2. The phrase "exotic species" in this context should not be confused with rare species such as birds, snakes, or monkeys, which are illegally trafficked.

3. Edward L. Mills et al., Exotic Species in the Great lakes: A History of 
harmful impacts that humans have had on ecosystems around the globe. ${ }^{4}$ When these invasive species become established in a new ecosystem, they have less competition for resources and fewer natural predators. These factors keep populations stable in their native habitat, but reproduction rates explode in the new ecosystem. ${ }^{5}$ This causes a host of ecological and economical harms including the destruction of indigenous species, the destruction of habitats, an increase in diseases, and negative impact on human activities that are connected to these ecosystems. ${ }^{6}$

\section{A. Laurentian Great Lakes and the Asian Carp}

The Laurentian Great Lakes are the world's largest group of fresh water surface lakes. ${ }^{7}$ They were formed between 14,000 and 4,000 years ago by the retreat of glaciers at the end of the most recent Wisconsin ice age

BIOTIC CRISES AND ANTHROPOGENIC INTRODUCTIONS 4 (1991), archived at http://perma.cc/9Y96-RQK6. Executive Order 13112 defines these organisms as, "(a) 'Alien species' means, with respect to a particular ecosystem, any species, including its seeds, eggs, spores, or other biological material capable of propagating that species, that is not native to that ecosystem." sec. 1, Exec. Order No. 13,112, 64 Fed. Reg. 6183 (Feb. 3, 1999). The Great Lakes Water Quality Agreement of 2012 defines aquatic invasive species as, any non-indigenous species, including its seeds, eggs, spores, or other biological material capable of propagating that species, that threatens or may threaten the diversity or abundance of aquatic native species, or the ecological stability, and thus water quality, or water quality of infested waters, or commercial, recreational, or other activities dependent on such waters.

Protocol Amending the Agreement Between the United States of America and Canada on Great Lakes Water Quality, 1978, as amended on October 16, 1983 and on November 18, 1987, U.S.-Can., annex 6(E), Sept. 7, 2012 [hereinafter 2012 Protocol Amending GLWQA], archived at http://perma.cc/GDX2-RBRA.

4. Edward L. Mills et al., Exotic Species and the Integrity of the Great Lakes: Lessons From the Past, 44 BIOSCIENCE 666, 666 (1994). Invasive species have been labeled as the second biggest cause of species endangerment and extinction. The combined impact was larger than "global warming, excessive harvesting, pollution, and disease." ProTECTING OUR GREAT LaKes: BALLAST WATER AND THE IMPACT OF INVASIVE SPECIES 24 (2005), archived at http://perma.cc/TMD6-2XJ4. Other reports have found that 46 percent of endangered species have been affected by invasives. NATIONAL INVASIVE SPECIES CounCIL, MEETING the Invasive Species Challenge: National Invasive Species Management Plan 2 (2001), archived at http://perma.cc/GFV5-B3UG.

5. K. M. Fletcher, If You Can't Beat'em, Eat'em: Legal Methods to Control Aquatic Nuisance Species in the Gulf of Mexico, 5 OCEAN \& COASTAL L.J. 245 (2000).

6. Id. Additionally, invasive species can interbreed with similar native species, forever changing the genetic makeup of the native. J. A. Boothe, Defending the Homeland: A Call to Action in the War Against Aquatic Invasive Species, 21 TuL. ENVTL. L.J. 407, 410 (2007).

7. "The drainage area of the Laurentian system (including the Saint Lawrence River) is approximately 1.0 million $\mathrm{km} 2$-approximately one-third of the Mississippi River watershed or roughly 4 percent of the surface area of North America." B. HALES, NORTH AMERICAN CONTINENTAL MARgINS: A SYNTHESIS AND PlanNING WORKSHOP: REPORT OF THE NORTH AMERICAN CONTINENTAL MARGINS WORKING GROUP FOR THE US CARBON CYCLE SCIENTIFIC STEERING GROUP AND INTERAGENCY WORKING GROUP 1 (2008). 
and contain about 21 percent of the surface fresh water on the planet. ${ }^{8}$ There are five principle lakes in the system: Superior, Michigan, Erie, Ontario, and Huron. ${ }^{9}$ The Lakes cover a wide expanse of territory and touch eight of the United States and one province of Canada. ${ }^{10}$ Surveys of the Great Lakes' ecology show that, despite their size, they are extremely vulnerable to invasive species, which could be one of the largest ecological threats to strike the region. ${ }^{11}$

Humans have introduced invasive species to the Great Lakes for well over 200 years. ${ }^{12}$ Experts believe indigenous people who lived in the Great Lakes region moved organisms between lakes so that now they all have similar ecological profiles. ${ }^{13}$ The rate that invasive species were introduced to the Great Lakes increased after French and other European settlers came to the region. ${ }^{14}$

As the level of introduction mechanisms and human activity in the Great Lakes has increased, the rate of invasive species introductions has also spiked. ${ }^{15}$ The majority of invasive species entered the Great Lakes during two periods of time. From the middle to the late 1800's invasive species entered the Great Lakes from canals, solid ship ballast, and through the deliberate introduction of fish species. ${ }^{16}$ The second period, from 1933 to 1990 , brought invasive species through ship ballast water, an unintentional release, fish stocking, and a canal introduction. ${ }^{17}$ Today, there are over 139 non-indigenous species in the Great Lakes. ${ }^{18}$

8. Basic Information, Region 5 US EPA, BASIC INFORMATION, $\mathrm{http} / / / \mathrm{www} . e p a . g o v / g \operatorname{lnpo} /$ basicinfo.html (last updated July 5, 2012, archived at http://perma.cc/B8SY-AHTX); see MILLS ET AL., supra note 4, at 6 . They also have 84 percent of the surface freshwater in North America. Basic Information, supra.

9. Basic Information, supra note 9.

10. See Mills et al., supra note 5, at 666. Canada has control over 41 percent of the lakes, with the United States controlling the other 59 percent. Joseph W. Dellapenna, International Law's Lessons for the Law of the Lakes, 748 (2007), archived at http://perma.cc/WK4N2XTE.

11. See Mills et al., supra note 5, at 666,672.

12. See Mills et al., supra note 5, at 666.

13. See MILLS ET AL., supra note 4, at 6.

14. See Mills ET AL., supra note 4, at 6.

15. See Mills ET AL., supra note 4, at 78. Experts have noted that as ship technology itself has improved, so has the chance of exotic species surviving a trans-ocean voyage. J. A. Ruiter, Combating the Non-Native Species Invasion of the United States, 2 DRAKE J. AGRIC. L. 259, 261 (1997). It has been suggested that as climate change warms the water in the lakes, they will become even more vulnerable to invasive species. Noah D. Hall, Climate Change and Great Lakes Waters Resources: Avoiding Future Conflicts with Conservation, 31 HAMLINE L. REv. 641, 649 (2008).

16. See Mills ET AL., supra note 4, at 83.

17. Mills ET AL., supra note 4, at 83.

18. Alfred M. Beeton, Large Freshwater Lakes: Present State, Trends, and Future, 29 ENVTL. CONSERVATION 21, 23 (2002). Estimates are that almost 10 percent of the species have had "serious" impacts. Mills et al., supra note 5, at 671; Ruiter, supra note 16, at 262. 
Invasive species have already significantly impacted our understanding of Great Lake ecology. So profound has been the impact of non-native species that some have noted that "almost the entire Great Lakes food web consists of nonindigenous species. Most of the organisms in the everyday lives of people who interact with the Great Lakes are invaders from another system."

For example, many of the fish that are commonly considered part of the commercial and sport fisheries in the Great Lakes were originally introduced by humans. The common carp was originally introduced to North America in 1831 by a "patriotic" private citizen. ${ }^{20}$ After 1879 these fish were stocked in the Great Lakes basin following a distribution by the United States Fish Commission. Today they support a commercial fishery. ${ }^{21}$ Similarly, various species of salmon, which are native to the West coast, have been introduced to create a sport fishery. Starting in 1873, Chinook Salmon were stocked in most of the Great Lakes, and this population has been restocked since 1967 to create a sustainable sport fishery. ${ }^{22}$ In 1933 Coho Salmon were introduced to Lake Erie and reintroduced in 1966 to create a reproducing population, which is supplemented to maintain their numbers. ${ }^{23}$ Finally, the Ontario Department of Lands and Forests accidentally introduced pink salmon in $1956 .{ }^{24}$

More recently, a number of related species collectively known as Asian carp are thought to have entered the Great Lakes through inadvertent introduction by humans. ${ }^{25}$ Many of these carp came into the region's

19. Reauthorization of the 1990 Nonindigenous Aquatic Nuisance Prevention and Control Act: Hearings on H.R. 3217 Before the Subcomm. on Fisheries, Wildlife and Oceans of the House Comm. on Resources, 104th Cong. (1996) (testimony of Russell A. Moll, Director, Michigan Sea Grant College Program), quoted in Ruiter, supra note 16, at 262.

20. See Mills ET AL., supra note 4, at 18. Invasive species in the Great Lakes today are about 42 percent plants, 18 percent fish, and 17 percent algae species. See MILLS ET AL., supra note 4 , at abstract. Another invasive species in the Laurentian Great Lakes is also worth noting. The zebra mussel has a huge impact on the Great Lakes region through its filter-feeding. Massive numbers of zebra mussels have disrupted the lakes ecosystem. It is estimated that they can filter the entire western basin in Lake Erie's basin every week. Ruiter, supra note 16, at 262-263. Filtration of this amount of water drastically changes the ecology of the lakes. The economic impact of the zebra mussels has been hard to estimate with any precision, but has been estimated at between three to five billion dollars annually. S. B. Zellmer, Virtues of Command and Control Regulation: Barring Exotic Species from Aquatic Ecosystems, U. ILL. L. REV. 1233, 1237 (2000). Zebra mussels are so fecund that they logged the water system in Monroe, Michigan and shut down the town's supply of drinking water. S. O'Shea \& A. Cangelosi, Trojan Horses in Our Harbors: Biological Contamination from Ballast Water Discharge, 27 U. ToL. L. REV. 381, 382 (1995).

21. Mills ET AL., supra note 4, at 18-19.

22. See Mills ET AL., supra note 4 , at 16.

23. See Mills ET AL., supra note 4 , at 16.

24. See Mills ET AL., supra note 4, at 15.

25. See Leif-Matthias Herborg et al., Comparative Distribution and Invasion Risk of 
waterways after the historical 1993 floods overwhelmed the catfish farm ponds where they were used for cleaning. ${ }^{26}$ These invasive and aggressive consumers eat up to 40 percent of their body weight each day, and they quickly outcompete native and introduced species for food. ${ }^{27}$ Currently, there is intense concern about the still unknown impacts of the Asian carp becoming fully established in the Great Lakes region, and there is significant pressure to enact scientific and policy-based solutions to their spread. $^{28}$

In these Lakes, the commercially viable yet invasive fish species have been less environmentally disruptive and pose less of a threat to the overall economic output of the Lakes. Other invasive fish species, such as the Asian carp, for which there is no widespread commercial use, are more problematic and as will be discussed, infra, ${ }^{29}$ have elicited a stronger policy response.

\section{B. African Great Lakes and the Nile Perch}

The African Great Lakes are a group of lakes in Eastern Africa in the Great Rift Valley. This rift valley is the result of the African and Eurasia continental plates pulling apart from each other. ${ }^{30}$ This creates two "branches" of lakes: the Eastern (the main section) and Western, though the largest of these lakes, Victoria (Nyanza), lies between these branches. ${ }^{31}$ There are fifteen lakes in this region, including Tanganyika, Malawi, Turkana, Kivu, Edward, and Albert. ${ }^{32}$ Lakes Victoria, Tanganyika, and Malawi combined have 25 percent of the planet's surface water. ${ }^{33}$ Unlike the Laurentian Lakes, not all of the African Great Lakes are

Snakehead (Channidae) and Asian Carp (Cyprinidae) Species in North America, 64 CAN. J. OF FISHERIES AND AQUATIC SCI. 1723, 1724, 1730, 1732 (2007).

26. Spencer Hunt, Carp DNA found in 2nd bay of Lake Erie, THE COLUMBUS DisPaTCH Sep. 26, 2012, archived at http://perma.cc/Y4X7-PRKY; Louisiana Chef's Solution to Asian Carp Invasion - Eat Them!, LouISIANA SEAFOOD NEWS.COM, Apr. 12, 2013, archived at http://perma.cc/BP4Q-XKLA.

27. See Herborg et al., supra note 26, at 1724; Dr. Michael J. Hansen, Chair, Great Lakes Fishery Comm'n, Statement to the House Committee on Transportation and Infrastructure, Subcommittee on Water Resources \& Environment: The Asian Carp Threat to the Great Lakes 3 (Feb. 9, 2010), archived at http://perma.cc/SQ93-W4MC.

28. See generally Hansen, supra note 28; Erik Stokstad, Biologists Rush to Protect Great Lakes from Onslaught of Carp, 327 SCIENCE 932 (2010).

29. Notes 79-81 and accompanying text.

30. See generally Marc Elieson, The Great Lakes of East Africa, CiCHLID-FORUM.COM, http://www.cichlid-forum.com/articles/lakes_east_africa.php, (last visited Feb. 25, 2014, archived at http://perma.cc/7XAM-NAPC).

31. Id.

32. Of the lakes in the region, only eight of the fifteen are considered large enough to be called "great lakes." See Great Lakes, PBS.ORG, http://www.pbs.org/wnet/africa/explore/ greatlakes/greatlakes_overview_lo.html (last visited Feb. 25, 2014).

33. Odada \& Olago, supra note 2, at 433. 
interconnected. ${ }^{34}$ The African Great Lakes rival the Laurentian Lakes in size and exceed them in biological diversity. ${ }^{35}$ Similar to the Laurentian Great Lakes, the ecological diversity of these bodies is a key to the economic strength of the region. ${ }^{36}$ Unlike the Laurentian Lakes, fisheries and other aquatic organisms are key to the livelihood of a large number of people living in the region. ${ }^{37}$ For example, in Malawi, 70 percent of the population's dietary protein comes from fish. ${ }^{38}$ Additionally, while fish are an important part of the local diet, they have also become critical for their role in foreign exchange and export. ${ }^{39}$ This means that when invasive species disrupt and harm the environment, the impact is felt strongly by the human population. ${ }^{40}$

The Nile perch Lates niloticus (Centropomidae) is one of the most pervasive and controversial invasive species in the African Great Lakes. In the 1950's Nile perch were introduced to Lake Victoria to stimulate commercial fisheries after land use changes harmed the lake water quality and resulted in reduced indigenous fish populations. ${ }^{41}$ Some scholars have noted that there was not a great deal of planning or consideration of the impacts. $^{42}$ While their populations remained relatively controlled for the

34. See African Great $\begin{gathered}\text { Lakes, } \\ \text { GLOBALGREATLAKES.ORG, }\end{gathered}$
http://www.globalgreatlakes.org/agl/ (last visited Feb. 25, 2014, archived at
http://perma.cc/9XNB-2TUW) (displaying a map of the African Great Lakes).

35. Harvey A. Bootsma \& Robert E. Hecky, A Comparative Introduction to the Biology and Limnology of the African Great Lakes, 29 J. OF GREAT LAKES RES. 3, 6 (2003).

36. Id.

37. The author also notes that the lakes are a major source of clean drinking water for the region. See Richard Ogutu-Ohwayo et al., Human Impacts on the African Great Lakes, SO ENVTL. BIOLOGY OF FISHES 117, 118 (1997).

38. Bootsma \& Hecky, supra note 36 , at 6 .

39. Bootsma \& Hecky, supra note 36 , at 7.

40. See generally Patricia Kameri-Mbote \& Collins Odote, Courts as Champions of Sustainable Development: Lessons from East Africa, 10 SustaINABLE DEv. L. \& POL'Y 31, 31-32 (2009). It is also worth noting the impact of other invasive species on the African Great Lakes. For example, the water hyacinth is similar to the zebra mussels in the Laurentian Great Lakes. This plant grows rapidly and takes up resources needed by other plants and animals. Zellmer, supra note 21 , at 1237 . In fact, it is one of the fastest growing plants in the world and has been described as one of the "world's worst tropical aquatic weed." Fletcher, supra note 6 , at 247 . The "[w]ater hyacinth forms lush green carpets" on the water, which raises the water's temperature, decreases the amount of sunlight that reaches organisms in the water, and decreases the amount of oxygen available. See Meddy Mulisa, Tanzania: Resurfacing Water Hyacinth Threatens Livelihood in Lake Victoria, TANZANIA DaILY NEWs, Dec. 7, 2012, archived at http://perma.cc/MWW2-U24P. This has a potentially devastating impact on the local populations who have a difficult time reaching fish because their nets may become tangled and boats stuck. See id.

41. Paul Saundry, World Wildlife Fund, LAKE VictorIa: THE ENCYCLOPEDIA OF EARTH, http://www.eoearth.org/view/article/154134/ (last visited Feb. 4, 2014, archived at http://perma.cc/3HG-K7SV).

42. Bootsma \& Hecky, supra note 36 , at 7. 
first twenty years after their introduction, they grew more quickly in the 1980 's and, as a result, destroyed the populations of many indigenous species of cichlids. ${ }^{43}$ Some estimates assert that as many as half of these species have been lost. ${ }^{44}$ This event has been described as "the greatest single paroxysm of extinction ever recorded., ${ }^{, 45}$

However, the story of the Nile perch is more complicated than the invasive fish species of the Laurentian Lakes. Currently, these invasive fish make up an impressive portion of the fish caught in the region and amount to as much as 63 percent of the catch from Lake Victoria. ${ }^{46}$ This Lake Victoria fishery alone comprises a quarter of the freshwater fish harvested in Africa. ${ }^{47}$ Therefore, they are an important economic aspect to the lake management and have not elicited as strong of a policy response.

\section{GOVERNANCE FRAMEWORKS TO ADDRESS INVASIVE SPECIES}

Invasive species have come under increasing regulation as a result of the considerable economic and environmental damage they cause. ${ }^{48}$ This has spawned a number of regulations at the state, federal, and international levels, which work together-both in the Laurentian and African contexts-to address the invasive issue in their own way.

Broad surveys of legislation addressing invasive species have found a host of shortcomings. Most legislation does not address all vectors of introduction; instead, it focuses on a piece-meal approach. ${ }^{49}$ Further, there is a lack of programs to address the eradication or management of invasive species once they have become introduced in an ecosystem. ${ }^{50}$ Most legislation is focused on reacting to a threat, rather than preventing the harm in the first place." Put in short, "the state of . . . [invasive] species

43. Bootsma \& Hecky, supra note 36 , at 7 .

44. A century ago, there were as many as five hundred different species of haplochromine cichlids. Marc Elieson, THE GREAT LAKES OF EAST AFRICA, http://www.cichlid-forum.com/articles/lakes_east_africa.php (last visited Feb. 4, 2014, archived at http://perma.cc/TFT3-9QRN).

45. Chris BRIght, Life OUT OF Bounds: BionNVASION IN A BORdERLESS WORLD (1998).

46. Saundry, supra note 42.

47. Bootsma \& Hecky, supra note 36 , at 7.

48. See generally Marc L. Miller \& Lance H. Gunderson, Biological and Cultural Camouflage: The Challenges of Seeing the Harmful Invasive Species Problem and Doing Something About $\mathrm{It}$, in HARMFUL INVASIVE SPECIES: LEGAL RESPONSES 1 (Marc L. Miller \& Robert N. Fabian eds., 2004) (noting that "[s]everal major international legal instruments and organizations have emphasized the importance of invasive species issues").

49. Lyle Glowka, Bioprospecting, Alien Invasive Species, and Hydrothermal Vents: Three Emerging Legal Issues in the Conservation and Sustainable Use of Biodiversity, 13 Tul. ENVTL. L.J. 329, 334 (1999).

50. Id. at 334.

51. Id. 
legislation worldwide ... appear[s] to be far from adequate." ${ }^{, 52}$

It is useful in this context to note how, even as the differences between natural and human-altered ecosystems have become more similar, the evolution of these regulatory regimes in both sets of lakes broadly mirrors the preservation and conservation dichotomies. Both philosophies desire to maintain and promote the natural environment. However, they go about their task in differing ways. Broadly put, conservation attempts to provide good stewardship over natural resources, in large part so that these resources in turn provide bounty for human use. Preservation attempts to minimize (if not eliminate) the impact on the environment from human use.

\section{A. Laurentian Lakes and the 2012 Great Lakes Water Quality Agreement}

In the Great Lakes region there are a number of legal instruments that overlap and create an unusually complicated "amalgam of international, interstate, and interprovincial, national, and state law," which can be described as the "law of the Lakes." ${ }^{33}$ However, the Laurentian Lakes have had trouble collectively addressing the invasive species problem, causing them to be described as "a quintessential commons that has seen its share of tragedies." 54 In the past, commentators have noted that the invasive species problem needs to be addressed with more innovative legislation. ${ }^{55}$ Looking at the history of legal instruments in the region shows that there is a broad evolution of protecting the environment from these species as the response has become more complex and nuanced. This is particularly seen in the shift from restricting individual species to addressing ways that protect the entire ecosystem. ${ }^{56}$

In 1900, the Lacey Act was passed to prohibit US citizens from trading certain organisms. The Act gives the Secretary of the Interior the power to name certain species of animals as "injurious ... to the interests of agriculture, horticulture, forestry, or to wildlife or the wildlife resources of the United States." 57 The Act made it a violation of federal law to trade any fish or wildlife which is prohibited by a law, treaty, or regulation of the United States, Indian tribal law, state or foreign law. ${ }^{58}$ The Lacey Act is criticized for being a slow and cumbersome way to deal with a quickly

52. Id. (alterations added).

53. See generally Dellapenna, supra note 11 , at 750 .

54. Hall, supra note 16 , at 662 .

55. Ruiter, supra note 16 , at 260.

56. See A. Dan Tarlock, Four Challenges for International Water Law, 23 Tul. ENVTL. L.J. 369, 369 (2009).

57. 18 U.S.C. $\$ 42(a)(1)(2014)$.

58. See 16 U.S.C. 3372(a)(1)-(2) (2014); see United States v. Condict, No. CR-05-004SPS, 2006 WL 1793235, at *1 (E.D. Okla. June 27, 2006) (finding that "wildlife" as used in the Lacey Act includes white-tailed deer, which defendant was charged with receiving, in violation of Oklahoma law). 
moving threat. ${ }^{59}$ More importantly, many invasive species inadvertently come to the United States or are inadvertently introduced into the environment. ${ }^{60}$ The Lacey Act has restricted a number of invasive Great Lake organisms, such as the zebra mussel and several species of Asian carp. ${ }^{61}$ However, these restrictions came long after the threat was already present in the ecosystem.

Individual states have also passed "mini-Lacey Acts," which ban the importation of the certain listed species. ${ }^{62}$ As laboratories of democracy, these states can act faster than the federal government. ${ }^{63}$ However, these laws suffer from the same issues as the federal Lacey Act. They are still unable to address any species that enter their waters unintentionally. Further, states are unable to induce compliance by other countries. For example, Michigan could ban Asian carp, but it would be unable prevent the importation of carp to Canada.

Another federal regulation which deals with invasive species is the Nonindigenous Aquatic Nuisance Species Act ("NANSA"). Congress passed this law in November 1990 in response to the projected impact of zebra mussels in the Great Lakes. ${ }^{64}$ The Act was aimed at the regulation of the shipping industry and had the goal of creating a "coherent program" to address the slow, unintentional introduction of new species. ${ }^{65}$ NANSA created a protocol to reduce the spread of invasive species though ship ballast water. ${ }^{66}$ States were also asked to draft comprehensive management plans and research the spread of invasive species within their borders to identify the most high-risk species. ${ }^{67}$ Federal funding was provided to help states develop "technical, financial, or enforcement" support necessary to eliminate or reduce the environmental public health and safety risks

59. See generally Andrea J. Fowler et al., Failure of the Lacey Act to Protect US Ecosystems Against Animal Invasions, 5 FrontIERS IN ECOLOGY \& THE ENVT. 353 (2007).

60. Ruiter, supra note 16, at 266.

61. See Fowler et al., supra note 60, at 355; Press Release, Carl Levin: U.S. Senator for Michigan, President Signs Levin's Asian Carp Prevention and Control Act into Law (Dec. 14, 2010), available at http://www.levin.senate.gov/newsroom/press/release/?id=14bf4e078476-4f36-ba03-91a9e7c52f27.

62. The Great Lake states that have passed this type of legislation include Minnesota, Wisconsin, and Michigan. Boothe, supra note 7, at 421.

63. Boothe, supra note 7, at 421.

64. Mills et al., supra note 5, at 674.

65. Fletcher, supra note 6 , at 250.

66. This process is not as effective for certain organisms that thrive in brackish water. Additionally, many ships are unable to effect a complete exchange because they cannot completely empty out the ballast, which they need for stability, without causing safety concerns. See Mills et al., supra note 5, at 674. Several exemptions to the ballast exchange program can have absurd results. For example, a captain of a ship with a poorly trained crew could claim a "safety" exemption. Zellmer, supra note 21, at 1239.

67. Fletcher, supra note 6, at 246. 
associated with aquatic nuisance species. ${ }^{68}$ However, a major drawback is that NANSA does not provide a specific framework to facilitate international cooperation. ${ }^{69}$

In 1996, NANSA was reauthorized, and its scope was expanded to include all waters in the United States. ${ }^{70}$ In addition to maintaining state management plans, the reauthorized (and renamed) National Invasive Species Act (NISA) created interstate management plans to expand cooperation between states. ${ }^{71}$ As state and interstate management plans have been developed, it has become clear states are focused on education whereas the federal approach involves greater regulation. ${ }^{72}$ Many commentators have noted that state plans create a "patchwork" of regulations and do not adequately develop a compressive approach. ${ }^{73}$

Another way that the federal government addressed the invasive species issue is through Executive Order 13,112, which formed an Invasive Species Council with representatives from the Departments of Commerce, Interior, Agriculture, Defense, State, Treasury, and Transportation. ${ }^{74}$ The order charged this council with identifying ways to respond to invasive species and restore destroyed habitats. The Council also focuses on promoting education to help the public understand the size of the invasive species threat. ${ }^{75}$ Unfortunately, this order is unable to affect private entities. $^{76}$

More recently, the 2012 Stop Invasive Species Act was introduced-but not enacted-to directly deal with the Asian Carp issue. ${ }^{77}$ This act directs the Secretary of the Army, acting through the Chief of Engineers, to conduct a study with the goal of preventing the spread of invasive species between the Great Lakes from the Mississippi River Basins, primarily focusing on the Chicago Sanitary and Ship Canal. ${ }^{78}$ The Act notes that this report should focus on physically separating the two water bodies but can also include technological methods. ${ }^{79}$

Finally, there are a number of laws passed that specifically target

68. Fletcher, supra note 6, at 251.

69. Ruiter, supra note 16 , at 268.

70. Fletcher, supra note 6.

71. Fletcher, supra note 6 , at 251.

72. Fletcher, supra note 6 , at 255.

73. Fletcher, supra note 6 , at 267.

74. Fletcher, supra note 6 , at 253.

75. Fletcher, supra note 6 , at 253.

76. See Jane Cynthia Graham, Snakes on a Plain, or in a Wetland: Fighting Back Invasive Nonnative Animals-Proposing a Federal Comprehensive Invasive Nonnative Animal Species Statute, 25 TUL. ENVTL. L.J. 19, 42 (2011).

77. See Stop Invasive Species Act, S. 2317, 112th Cong. (2012); H.R. 4406, 112th Cong. (2012).

78. S. $2317, \S 2$ (b)(2).

79. See Stop Invasive Species Act, S. 2317, 112th Cong. (2012). 
single species of invasive organisms. For example, the Brown Tree Snake Control and Eradication Act of 2004 was designed to facilitate the funding of "control, interdiction, research, and eradication efforts" to destroy this snake. ${ }^{80}$ These single species programs are reactive and only deal with invasive species after they are established and have begun causing ecological and economical damage. ${ }^{81}$

As noted, the drawback to many of these programs is that they are limited in their ability to address the problem through a multi-jurisdictional approach. With enforcement gaps, the overall goal of reducing invasive species is hard to achieve. A multi-jurisdictional approach would harmonize policies between two or more states. Keeping this in mind, there have been a number of attempts to address the invasive species issue in the Laurentian Great Lakes though intrastate or international agreements.

In 1968, the Great Lakes Basin Compact and Commission was created by the US Congress. The Commission helped states exchange information and carry out programs for the benefit of the Lakes. ${ }^{82}$ Costs for these programs were allocated to each state based on the amount of economic interest they had in the Lakes. ${ }^{83}$ A major drawback to the Commission is that its recommendations did not have the force of law. ${ }^{84}$

The 1978 Great Lakes Water Quality Agreement encouraged the United States and Canada to use and manage the Lakes based on an ecosystem-wide approach. ${ }^{85}$ The Agreement was designed to restore the lake ecosystem after a period of significant pollution. ${ }^{86}$ It outlined six themes to address pollution, including creating specific roles for each government, drafting action plans, and involving the public. ${ }^{87}$ The Agreement is particularly useful because it created a "framework-protocol" to address individual aspects (such as invasive species) under the umbrella of the wider agreement. ${ }^{88}$ Some commentators have noted that "the

80. See Graham, supra note 77 , at 46 . Another example is the Nutria Eradication legislation. Id. at 47 .

81. Graham, supra note 77 , at 48 .

82. Members of the Compact include Illinois, Indiana, Michigan, Minnesota, New York, Ohio, Pennsylvania, and Wisconsin. The members have three votes, and it requires a majority of votes to pass a decision, but if the Commission is sending a new program to the states, it requires a majority of each states' votes. Dellapenna, supra note 11, at 750 .

83. Dellapenna, supra note 11,751 .

84. Dellapenna, supra note 11 , at $751-752$.

85. The International Joint Commission (IJC) was a body created through the 1909 United States and Canada Boundary Waters Treaty and was intended to carry out programs, to adjudicate disputes, and to provide suggestions that could improve the governance of the lakes. See Tarlock, supra note 57, at 391-392; Jutta Brunnee \& Stephen J. Toope, Environmental Security and Freshwater Resources: Ecosystem Regime Building, 91 AM. J. INT'L L. 26, 52, 55 (1997).

86. See Brunnee \& Toope, supra note 86 , at 52 .

87. See Brunnee \& Toope, supra note 86 , at 52-53.

88. See Brunnee \& Toope, supra note 86 , at 56. 
framework-protocol model has proven itself in various settings characterized by significant developing country participation.",89

The Great Lakes-St. Lawrence River Basin Water Resource Counsel and the Great Lakes-St. Lawrence Water Resources Regional Body were created by the 2008 Great Lakes-St. Lawrence River Basin Compact and Agreement. ${ }^{90}$ This management organization for the Lakes has the power to set and enforce policy, which gives it a stronger hand in guiding the development of the Lakes. The Compact was signed by representatives of each American state, while members in Canada signed the similar Great Lakes Agreement. This allowed the region to create a durable institution, without the more onerous trouble of formal treaty negotiation and ratification at the federal level. ${ }^{91}$

In 2012, the Great Lakes Water Quality Agreement was amended to put invasive species in brighter focus. ${ }^{92}$ The invasive issue is included in the implementation of the protocol and addressed as a specific objective of the Agreement framework. This new Agreement recognizes that improving the waters of the Great Lakes requires a movement from an individualized response to an ecosystem approach which considers "individually and cumulatively all sources of stress to the Great Lakes Basin Ecosystem." ${ }^{.93}$

The Agreement takes a number of important steps, within the useful and innovative framework-protocol approach, in the way that it formulates its response to the invasive species problem. First, it attempts to regulate and prevent the spread of invasive species in as many vectors as possible. ${ }^{94}$ To this end, the Agreement sets forth a plan to address all new invasive species though prevention rather than reacting after they have become established. This process is guided by risk assessments and discovering the impacts of "established and high-risk" invasive species. ${ }^{95}$ Finally, the annex directly addresses the issue of eradicating the invasive species after they have become established. ${ }^{96}$

The experience in the Laurentian Great Lakes shows that there has been a gradual but steady evolution of law and policy towards invasive species. There has been a shift from a policy such as the Lacey Act, which is highly reactionary and has jurisdictional limitation. The new agreement employs an adaptable flexibility, which is designed to address all invasive species in a proactive approach that would "protect, restore, and enhance

89. Brunnee \& Toope, supra note 86 , at 56 .

90. Tarlock, supra note 57 , at 391.

91. Dellapenna, supra note 11 , at 782 .

92. See 2012 Protocol Amending GLWQA, supra note 4, art. 3(1)(a)(vii).

93. See 2012 Protocol Amending GLWQA, supra note 4, app.

94. See 2012 Protocol Amending GLWQA, supra note 4, annex 6(B)(2).

95. 2012 Protocol Amending GLWQA, supra note 4, annex 6(C).

96. See 2012 Protocol Amending GLWQA, supra note 4, annex 6. 
water quality of the Waters of the Great Lakes. ${ }^{, 97}$

\section{B. African Great Lakes and Lake Victoria}

The countries of Burundi, Rwanda, the Democratic Republic of the Congo, Uganda, Kenya, and Tanzania are usually considered as comprising the Great Lakes region. Unlike in the Laurentian Great Lakes, there are no overarching international agreements that address the whole group of African Great Lakes. Some major lakes have their own specific instruments, and each country has their own domestic laws regarding invasive species. Because there is a lack of strong institutions to address the invasive species, the African Great Lakes' policies are less integrated than the Laurentian Great Lakes, and any action suffers from a lack of coordination. ${ }^{98}$

Similar to the Laurentian Lakes, each state in the African Great Lakes region has its own legislation to address invasive species. While many of these are broadly similar, the overall picture is helpful in understanding how the issue is conceptualized and addressed. Lake Victoria, in relation to Kenya, Tanzania, and Uganda, will be considered for the purposes of this discussion because this is the largest lake in the system, the governance of this lake is the most evolved, and the Lake is the most similar to the Laurentian Lakes as it confronts issues managing its invasive species.

In Kenya, the Environmental Management and Coordination Act (EMCA) states that no one can introduce an invasive animal or plant to river, lake, or wetland, without first having the permission of DirectorGeneral and having an Environmental Impact Statement completed to assess the results of this change on the ecosystem. ${ }^{99}$ The Act further empowers the National Environmental Management Authority to issue laws that are needed for the conservation and protection of indigenous species from the harmful effects of invasive species. The EMCA was followed by the 2006 Conservation of Biological Diversity and Resources, Access to Genetic Resources and Benefits Sharing Regulations. ${ }^{100}$ These regulations cover protected areas and promote biological diversity and also require an environmental impact statement before invasive species can be introduced. ${ }^{101}$ While these laws show that there is a trend away from reactionary policies, there is still a lack of effective action. Government

97. 2012 Protocol Amending GLWQA, supra note 4, app.

98. See generally Kameri-Mbote \& Odote, supra note 41, at 31-32; Odada \& Olago, supra note 2 , at 433 .

99. Environmental Management and Coordination Act, No. 8 (1999) (Kenya), archived at http://perma.cc/42N-MNDR.

100. The Environmental Management and Co-ordination Act (Conservation of Biological Diversity and Resources, Access to Genetic Resources and Benefit Sharing) Regulations, 2006 (Kenya), archived at http://perma.cc/929J-CQW8.

101. Id. 
reports have noted that there must be a clear application of these laws because the "mandate ... is not particularly clear." "102

In Tanzania, the 2004 Environmental Management Act section 67(2) specifically allows the Minister of the Environment to draft regulations to prevent the introduction and control of or to eradicate invasive species which threaten ecosystems, habitats, or other species. ${ }^{103}$ These regulations also make it an offense to introduce invasive species without authorization. ${ }^{104}$ The National Fisheries Policy is more stringent, stating that it is illegal for anyone to move an invasive species from one body of water to another without permission. ${ }^{105}$ This policy also notes that the Minister of the Environment can create regulations, which restrict the importation of invasive species. $^{106}$

In Uganda, many of the laws reference invasive species. However, many of these only deal with the issue in an indirect way, and there are no laws that directly address invasive species. ${ }^{107}$ These include the National Environment Management Policy (1994) and Fisheries Policy (2000). ${ }^{108}$ The National Environmental Management Policy merely suggests that the government should create a strategy to produce an environmental impact assessment for invasive species. ${ }^{109}$ The Ugandan Fisheries Policy is the clearest statement on the issue of invasive species. This document starts by noting that the introduction of invasive species has caused a reduction on

102. In Kenya there is a significant threat from water hyacinth in Lake Victoria. This and other invasive plant species are addressed by the Suppression of Noxious Weeds Act. REPUBLIC OF KENYA, FOURTH NATIONAL REPORT TO THE CONFERENCE OF THE PARTIES OF THE CONVENTION ON BIOLOGICAL DIVERSITY (KENYA) 21, 58-59 (2009), archived at http://perma.cc/92QR-8JFB.

103. Tanzania, EnVIRonmental Management ACT, No. 20 (2004), archived at http://perma.cc/W93W-DS8R.

104. Id.

105. TANZania, The Fisheries ACt (TANZania) 13.

106. Id. at $17(\mathrm{k})$.

107. NAT'L Agric. Res. Org., The EnABling Policy and InStitutional ENVIRONMENT FOR INVASIVE Plant MANAGEMENT IN UgANDA 7, 9 (2004), archived at http://perma.cc/77NU-HNPB; NAT'L AGRIC. RES. ORG., THE NATIONAL INVASIVE SPECIES Strategy, ACtion Plan and POlicy Guidelines for Uganda ix (2007), http://perma.cc/5H5-UZ5M.

108. Ugandan laws which also address invasive species but which are less germane to the Great Lakes include the Uganda Forestry Policy (2001), National Forestry Plan (2002), National Forestry and Tree Planting Act (2003), National Wetlands Policy (1995), The Plant Protection Act Cap 31 (1962), The Plant Protection and Health Bill (2003), Wildlife Policy (1999), Wildlife Act Cap 200 (1996), Agriculture Policy (2003), and National Environmental Act Cap 153 (1995). Convention ON Biological Diversity, Bioinvasion and Global Environmental Governance: The Transnational Policy Network on INVASIVE ALIEN SPECIES 1-2, archived at http://perma.cc/SFR4-7UGS.

109. Ministry of Natural Res., National Environmental Management Policy (Uganda), archived at http://perma.cc/DQP8-27AC. 
lake biodiversity and resulted in the need to revise the existing policies. ${ }^{110}$ It follows the precautionary principle to limit the introduction of invasive species. ${ }^{11}$ The 1992 Rio Declaration succinctly describes the precautionary principle as "the lack of full scientific certainty shall not be used as a reason for postponing cost-effective measures to prevent environmental degradation." 112 The government is charged through this fisheries policy to "regulate and control" the introduction of invasive fish. ${ }^{113}$ However, it is clear that this fisheries policy is only an outline for action and does not create laws or policies which are enforceable.

Similar to the Laurentian Great Lakes, there are also international agreements in Lake Victoria that guide the management of these water resources. While these agreements have the same broad goals to protect and promote shared waters as the 2012 Great Lakes Water Quality Agreement, the key differences of how invasive species are treated comes through how economic and environmental interests are weighted.

Lake Victoria has a longer history of multi-lateral coordination than other lakes in the system because Kenya, Uganda, and Tanzania all shared a common colonial power. ${ }^{114}$ Although this history of joint action goes back to 1928 and includes the 1947 East African Freshwater Fisheries Research Organization (EAFFRO), only more recently have the countries worked together to address invasive species. ${ }^{115}$ Scientists and policy makers noted that without a system of joint management, it would be difficult for Lake Victoria to address the numerous environmental concerns that threaten it, including invasive species. ${ }^{116}$

In 1993, the Agreement for the Establishment of a Permanent Tripartite Commission for Co-operation was signed by Kenya, Uganda, and Tanzania. This was quickly followed by the 1994 Agreement on the Preparation of a Tripartite Environment Management Programme for Lake Victoria. ${ }^{117}$ This document was intended to foster coordination between these states that share the Lake. Although this document points out that the Lake's fisheries have undergone "changes" which have impacted the indigenous species, it does not specify the nature of these changes. ${ }^{118}$

110. DEP'T OF Fisheries Res., NATIONAL Fisheries Policy (UGANDA) 5 (2004).

111. Id. at 8 .

112. U.N. Conference on Environment and Development, Rio Declaration on Environment and Development, princ. 15, Aug. 12, 1992, U.N. Doc. A/CONF.151/26 (Vol. I).

113. NATIONAL Fisheries POLICY (UgANDA), supra note 111, at 20.

114. Bootsma \& Hecky, supra note 36 , at 7 .

115. Bootsma \& Hecky, supra note 36, at 7; Global ENVTL. FaCiLITy, LaKe Victoria ENVIRONMENTAL MANAGEMENT PROJECT 15, archived at http://perma.cc/YE6U-9NPQ.

116. GLOBAL ENVTL. FACILITY, supra note 116, at 16.

117. Agreement on the Preparation of a Tripartite Environmental Management Programme for Lake Victoria 1994, Kenya-Tanz.-Uganda, Aug. 5, 1994.

118. Id. 
Other programs such as the Technical Corporation for the Promotion of the Development and Environmental Protection of the Nile Basin (TECCONILE) have been devised for the overall coordination of sustainable development in the overall Nile Basin, which includes Lake Victoria. ${ }^{119}$ It is claimed that the management of invasive species falls under the umbrella of this organization. ${ }^{120}$

The Lake Victoria Environmental Management Project was developed by the World Bank, funded though the Global Environmental Facility and renewed most recently in 2009. ${ }^{121}$ This example of a development program, instituted by an outside donor, works with the Lake Victoria countries. Evaluations of past donor projects had shown that uncoordinated actions would be largely ineffective. ${ }^{122}$ Therefore, this program was designed to coordinate action by the basin's member states to form organizations that would jointly deal with the Lake's issues. ${ }^{123}$ This program attempted to connect disparate issues such as "invasive species, navigation, migration, biodiversity, disease, deforestation, and power generation" so that environmental ends were made more "mainstream." 124

The 2003 Protocol for Sustainable Development of Lake Victoria Basin was concluded between Kenya, Uganda, and Tanzania. ${ }^{125}$ The protocol singles out invasive species, ${ }^{126}$ but it only focuses on the introduction of invasive species if they are "detrimental" to the ecosystem of the Lake. ${ }^{127}$ Further, the protocol fails to develop steps to carrying out

119. The Enabling Policy and Institutional Environment for InVasive Plant MANAGEMENT IN UGANDA, supra note 108, at 23.

120. The Enabling Policy and Institutional Environment for Invasive Plant MANAGEMENT IN UGANDA, supra note 108, at 23.

121. Other examples include FAO Committee for Inland Fisheries of Africa (CIFA) and CIFA Sub-Committee for Lake Victoria. Global ENVTL. FACILITY, supra note 116.

122. Global ENVTL. FACILITY, supra note 116, at 19, para. 19. The Convention on the Sustainable Management of Lake Tanganyika was signed by the governments of Burundi, the Democratic Republic of Congo, Tanzania, and Zambia in 2003. This instrument contains less protection for the environment vis-à-vis invasive species than the Lake Victoria Protocol. While the Convention supports biological diversity, it undercuts the protection for indigenous species. The instrument specifies that invasive species should not be introduced unless other states give their consent, which "shall not be withheld unreasonably." This instrument encourages granting permission to introducing new species to the lake ecosystem. Convention on the Sustainable Management of Lake Tanganyika, Burundi-Dem. Rep. Congo-Tanz.-Zam., June 12, 2003, Lake Tanganyika Authority, archived at http://perma.cc/ZG2A-5PBQ.

123. GLOBAL ENVTL. FACILITY, supra note 116.

124. Andrea K. Gerlak, One Basin at a Time: The Global Environment Facility and Governance of Transboundary Waters, 4 GLOBAL ENVTL. POL. 108, 124 (2004).

125. Protocol for Sustainable Development of Lake Victoria Basin, Kenya-UgandaTanz., art. 33, Nov. 29, 2003.

126. Id.

127. Id. 
this goal. ${ }^{128}$ The Protocol specifically notes that fisheries should be run in accordance with the Convention establishing the 1998 Lake Victoria Fisheries Organization (LVFO). ${ }^{129}$

A purely exegetical approach shows that the LVFO is more lax than the Protocol. ${ }^{130}$ The LVFO "consider[s] and advise[s]" regarding the impacts of invasive species on non-indigenous species. ${ }^{131}$ The instrument notes that invasive species such as the Nile perch play a large role in commercial catches and these populations have caused a reduction in the indigenous fish species and decreased lake biodiversity. ${ }^{132}$ To enforce these regulations, the LVFO outlines that each state will use their national laws, which have already been discussed, to prohibit introduction of species prohibited by the Council of Ministers. ${ }^{133}$

\section{FINDING SOLUTIONS IN THE AFRICAN GREAT LAKES}

It is clear that policy towards fighting invasive species is following behind the science and even further behind the rate at which this threat is entering ecosystems. Each ecosystem will find its own solutions, which uniquely fit that area and are the product of the history, culture, ecology, and economy of the people who draft them. However, it is easily seen that the Laurentian Lakes have a longer history of invasive species legislation on both a national and international level than the African Lakes.

The Laurentian Lakes have adopted policies that merged national and international approaches to create a multi-jurisdictional approach to invasive species. Starting from the Lacey Act, these policies have evolved towards the Great Lakes Water Quality Agreement of 2012. Several themes can be seen by this gradual shift. First, identifying and banning invasive species is not effective. Invasive species are usually well established before this can be completed and it does not adequately address all vectors of introduction. The same can be said for specific laws that target certain invasive species. While this may help aim funding for remedial management and ecosystem restoration, it is an inadequate tool for prevention and comes far after the invasion has become a serious threat. Second, a piecemeal approach does not protect the lake ecosystem. If one jurisdiction has inadequate safeguards, then this weak link can result in invasive species being established. At times, due to difficulty in passing treaties at the federal level, countries may find it helpful to consider

128. Id.

129. Id.

130. Convention for the Establishment of the Lake Victoria Fisheries Organization, Kenya-Uganda-Tanz., art. XXII, June 30, 1994, 36 I.L.M. 667.

131. Id. art. II, s. 3(f) (alterations added).

132. Id. Preamble.

133. Id. 
innovative legislative paths. Third, the environmental problems facing the Lakes are too complex to be completely dealt with through a typical treaty. The framework-protocol approach gives states the flexibility to establish avenues for coordination, while also introducing ways to deal with specific issues. Fourth, combating the invasive species issues requires fully understanding their impact on the ecosystem though threat assessments which study their impact.

In Lake Victoria, and the African Great Lakes in general, there is a greater need for coordination. First, the many states of the region should work together to manage these water bodies. Though not every lake is hydrologically connected, they share much of the same ecosystem. In a period of time when human interaction is increasing the rate at which invasive species are being spread, there is a strong presumption towards joint management of resources. As suggested, this may require innovative legislative strategies. Second, these states should draft new treaties for the management of these lakes that follow the framework-protocol model. This model is common in environmental treaties and helpful in allowing specific issues, such as invasive species, to be fully addressed and in assigning specific rights and obligations for each signatory country. This would additionally allow them to avoid the fragmented approach that has hampered effective action. Finally, states need to adopt strategies that are ecosystem focused, and while understanding the role that some fish species may play economically, seek to stabilize the environment for long-term sustainable use. This should include threat assessments on both established and new invasive species, and find approaches that deal with each.

\section{CONCLUSION}

The Laurentian and African Great Lakes each have significant issues with invasive species. These organisms from other ecosystems have become established in the lakes and are causing rapid changes to the overall environmental health of the lakes as well as their economical outputs. In the Laurentian Lakes, the response to invasive species has moved from a highly reactionary approach that primarily addressed intentional introductions, towards a preventive ecosystem-based approach. However, in these lakes, the commercially viable invasive fish play a far less important economic role.

In the development of the economy and the protection of the ecology in the African Great Lakes, invasive fish species have played a different role. As seen by the Nile Perch in Lake Victoria, invasive species can become important to the life and livelihoods of people in the region. However, this does not mean that they pose any less of a threat to the overall environmental diversity, or that policy responses should be any less vigorous.

In the future, African Great Lakes states should model future multi- 
jurisdictional international agreements on the Great Lakes Water Quality Agreement of 2012. This should include the protocol-framework style, which allows for specific issues to be addressed in detail under the rubric of the larger agreement. Second, these agreements should take a preventive approach which attempts to combat invasive species through all the vectors by which they can be introduced to an ecosystem. Finally, governments need to work together to understand, predict, and mitigate the impacts of exiting invasive species and take an ecosystem-wide approach to dealing with these species. 
